\title{
Invited review: Genetic considerations for various pasture-based dairy systems
}

\author{
S. P. Washburn ${ }^{1}$ and K. A. E. Mullen \\ Department of Animal Science, North Carolina State University, Raleigh 27695-7621
}

\begin{abstract}
Pasture-based dairy systems use grazing to supply significant percentages of the dry matter intake of cows and heifers. Such systems vary from those for which pasture is used only as a supplemental feed for cows primarily fed a total mixed ration to those for which pasture is the primary source of dry matter for the herd. Cows that are optimal in a pasture system share many general characteristics with cows that are appropriate for a nonpasture system, including feed efficiency, maintenance of body condition, reproductive fitness, udder health, longevity, and the ability to adapt to various management systems. However, in such divergent feeding systems, the relative importance of various traits can differ. In pasture systems where cow nutrient demand intentionally coincides with seasonal forage availability, the focus of selection has emphasized fertility and other fitness traits, as well as yields of milk or milk components. Breeds or strains with higher yields of protein and fat typically have advantages in grazing systems that supply milk to solids-based or cheese markets. Holstein cows with high percentages of North American ancestry can work well in grazing systems that include supplemental concentrates or partial mixed rations, particularly if calving intervals are less restrictive. Crossbred cows can be selected for use in specific grazing systems as well as for specific milk markets, with the added advantage of heterosis. Breeds and crosses with high fertility are important for seasonal breeding and calving. The ability of cattle to both milk and maintain sufficient body condition for reproduction is important for any dairy production system but is critical in a seasonal system. Dairy farms that depend on pasture for most of dry matter for cows typically have lower production per cow than nongrazing dairies but have the potential to be economically competitive because of lower operating and overhead costs. Although the principles of selection are similar across a variety of pasture-based and nonpasture
\end{abstract}

Received January 9, 2014.

Accepted July 5, 2014.

${ }^{1}$ Corresponding author: Steve_Washburn@ncsu.edu systems, we document from studies and observations covered herein that optimal breeds, breed strains, and selection strategies can differ based on varying management constraints and objectives.

Key words: pasture, systems, genetics, management

\section{INTRODUCTION}

To discuss the genetics of cattle used in pasture-based dairy systems, a characterization of pasture-based systems is needed. A pasture-based system can vary from those for which pasture is used as the primary source of nutrients to systems in which pasture is only used as supplemental forage for cattle primarily fed a TMR. Most dairy graziers in New Zealand (NZ) use pasture systems in which cows get high percentages of daily and annual rations from grazing. Some farmers do use significant amounts of imported feeds and stored forages, particularly early and late in the grazing season (DairyNZ, 2010). In most NZ herds, cows are bred to calve corresponding with the grazing season (DairyNZ, 2013a). Many farmers in Ireland (IE) also employ seasonal calving, so that cows calve in late winter or early spring and have abundant high-quality pasture in early lactation and during rebreeding (O'Mara, 2008). In the United States (US), the use of pasture varies widely because of diverse environments with many species of forages, climate differences, and the availability of a diverse selection of supplemental feeds. Although many newer pasture-based herds are seasonally calved in the US, that practice is not as widespread as in NZ or IE. In Latin America, various parts of Europe, and elsewhere, pasture-based systems are common and, in some cases, more prevalent than nonpasture systems. In more tropical areas, producers rely on abundant solar energy for pasture production and use crossbreeding with Bos indicus cattle to take advantage of increased heat tolerance, disease resistance, and adaptation to coarse pastures (Madalena et al., 2002). However, traditional pure dairy breeds and crosses among those breeds are used in pasture systems in Central and South American countries in more temperate climates based on latitude and elevation (Dini et al., 2012; Ferreira, 2013, and personal observations by authors). 
The number of pasture-based dairies in the US has increased in the past $20 \mathrm{yr}$. Kriegl and McNair (2005) noted an increase of pasture systems in Wisconsin from $7 \%$ of dairy farms in 1993 to $23 \%$ in 2003 , and about one-third of Wisconsin dairy farms surveyed in 2010 used at least some pasture for lactating dairy cows (USDA-NASS, 2010). Survey data from 2006 indicated that about $13 \%$ of dairies in 4 northeastern states $(20 \%$ of Vermont farms, $7 \%$ of Pennsylvania farms, and $11 \%$ of New York and Maryland farms) practiced management-intensive or rotational grazing (Winsten et al., 2010). They noted that percentages of grazing farms were up by 3 and 8 percentage units in Pennsylvania and Vermont, respectively, compared with 10 yr earlier. Based on personal communication with dairy graziers, pasture-based dairy systems have expanded in several states in recent years, most notably in Missouri, Florida, and Georgia, in addition to the states mentioned above.

Much of the management of pasture-based dairies is dictated by climate, governing which types of pasture forage will be able to grow. Stocking rates, supplemental feeding, pasture species, breed choices, and animal management can all vary widely and be adapted to suit various lifestyles and markets. Genetic selection within these extremely variable systems depends upon the goals of the producer and the feeding and management systems in use. The goal of some dairy graziers is to match pasture resources with the nutritional requirements of the animal such that seasonal breeding and calving may be advantageous.

The current review covers management concepts and genetic selection principles for grazing systems in subtropical to temperate climates with Bos taurus breeds of cattle. It is not the intent of this review to explore pasture-based dairy production systems in hot climates; for more information on that topic, see the review by Berman (2011). Our focus is to examine available research with various breeds, strains within breed, and crosses in representative grazing environments and to summarize such information relative to performance in such systems. In addition to reviewing various published reports, some observations from direct interactions with dairy graziers are also included. A listing of breeds and abbreviations used in this review are included in Table 1.

\section{BREEDING VALUES AND SELECTION INDICES}

Production of milk, feed efficiency, and other economics-related traits are important to all dairy production systems. However, such divergent feeding strategies as pasture-based and dry lot-fed systems may affect the relative importance of genetic traits used in selection programs. Horan et al. (2005a) stated that "ultimately, the optimum cow for pasture-based systems can only be identified by combining all traits of economic significance in a weighted index of economic merit and choosing sires at the top of this index." This principle can be applied equally to both pasture-based and non-pasturebased systems but weightings would be expected to vary across differing economic circumstances.

\section{Genetic Parameter Comparisons Between Pasture- Based and Non-Pasture-Based Dairy Systems}

Concern has been expressed that a typical sire evaluation program, such as information published by the USDA's Animal Improvement Programs Laboratory, would not be applicable to dairy graziers because of the difference in environment between dairies used to establish the evaluation and the environment of grazing dairies. Kearney et al. (2004a) reported a lower correlation between yield traits and PTA for grazing herds compared with confinement herds in the US. However, studies have reported few significant genotype $\times$ environment interactions in grazing versus confinement systems in Wisconsin (Weigel et al., 1999), Canada (Boettcher et al., 2003), the US (Kearney et al., 2004b), and NZ (Macdonald et al., 2008b). Minimal genotype $x$ environment interactions were reported for data from multiple countries for many traits; however, when using sires from another country, differences could exist in sire evaluation methods (Norman et al., 2006).

Although most genetic estimations in North America are based on data from non-pasture-based herds, those values are still reasonably accurate for use on grazing herds. Ranking of bulls would be different for a grazing system based on differences in phenotypic correlations, but the cost of creating a grazing-specific sire evalu-

Table 1. Abbreviations used for dairy breeds included multiple times in this review

\begin{tabular}{ll}
\hline Breed $^{2}$ & Abbreviation \\
\hline Ayrshire & AY \\
Brown Swiss & BS \\
Guernsey & GU \\
Holstein $^{3}$ & HO \\
Holstein-Friesian $^{4}$ & HF \\
Jersey $_{\text {Montbéliarde }}$ & JE \\
Normande & MB \\
Norwegian Red & NM \\
Swedish Red & NR \\
\hline
\end{tabular}

${ }^{1}$ Dairy breeds not included here were omitted because of very small populations or lack of relevant data. Such breeds may be of interest and use for meeting specific goals on some farms.

${ }^{2}$ Crossbred cattle are not included in the table but are included in the text with an " $\times$ " between respective breeds; e.g., JE $\times \mathrm{HO}$ and $\mathrm{HO} \times \mathrm{JE}$ are reciprocal crosses between JE and $\mathrm{HO}$.

${ }^{3}$ North American HO or closely related strains of HO.

${ }^{4}$ Friesian cattle with lower kinship to North American HO. 
Table 2. Estimated breeding values and heritability of traits for grazing or confinement dairy systems in Canada, the United States, and Ireland

\begin{tabular}{llc}
\hline Item & Grazing & Confinement \\
\hline EBV $^{1}$ & & \\
Milk production $^{1}$ & 0.31 & 0.37 \\
Fat kg $^{1}$ & 0.35 & 0.39 \\
Protein kg $^{1}$ & 0.30 & 0.36 \\
Fat $^{1}$ & 0.70 & 0.67 \\
Protein $^{1}$ & 0.61 & 0.64 \\
Mammary system $^{1}$ & 0.13 & 0.20 \\
Feet and legs $^{1}$ & 0.17 & 0.17 \\
Frame and capacity $^{1}$ & 0.27 & 0.34 \\
Heritability $^{2}$ & & \\
Days to first service $^{2}$ & 0.020 & 0.047 \\
Services per conception $^{2}$ & 0.007 & 0.030 \\
Calving interval $^{1}$ & $0.052^{1}, 0.04^{3}$ & $0.027^{1}$ \\
\hline
\end{tabular}

${ }^{1}$ Estimates from Canada (Boettcher et al., 2003).

${ }^{2}$ Heritability estimates from the United States (Kearney et al., 2004b).

${ }^{3}$ Estimate from Irish pasture-based dairies (Olori et al., 2002).

ation program would likely exceed potential benefits according to Kearney et al. (2004a). Fahey et al. (2007) did caution that dairy graziers with lower levels of production need to realize that bull PTA for yield traits might not be as accurate for predicting future performance in their herds compared with non-pasture-based herds or to grazing herds at higher levels of production. Also, because cows in pasture-based systems may tend to have improved health and longevity from not being on concrete most of the time, the relative importance of various fitness traits in a selection index may shift accordingly.

Estimated breeding values for milk yield traits (overall yield, fat yield, protein yield, mammary system) and feet and legs have been reported to be numerically higher in non-pasture-based Holstein (HO) herds than in grazing $\mathrm{HO}$ herds in Canada, but EBV of frame and capacity were similar across management types (Boettcher et al., 2003). Heritability estimates of reproduction traits were similar across management types from evaluations in multiple countries (Table 2). Although heritability of reproductive traits is low, there is variation and therefore genetic progress can still be made. For example, the annual increase in PTA for daughter pregnancy rate is projected at 0.17 percentage units with a cumulative expected increase in breeding value of 3.5 percentage units for daughter pregnancy rate in $10 \mathrm{yr}$ in the US (Cole et al., 2010). Differences in breeding values and heritability values for milk yield, conformation, and reproductive traits between nonpasture-based and grazing systems are low enough that graziers can use genetic information calculated from confinement herds with reasonable confidence.

Genetic values obtained from a chiefly pasture-based dairying countries such as NZ or IE can also be of use to graziers in the US. New Zealand's dairy cow population was approximately $75 \%$ Jersey (JE) until 1960, when the genetics of the population shifted with use of HO and Holstein-Friesian (HF) semen from both the US and NZ (Harris, 2005). Some graziers in the US have used NZ genetics (JE, HF) in their herds for various reasons, and the use of NZ genetics in US grazing herds has been investigated. Norman et al. (2006) compared $\mathrm{HO}$ or HF daughters of NZ AI bulls with $\mathrm{HO}$ daughters of US HO bulls (Table 3). Although advantages in reproductive traits were evident for NZ-sired cows, lower milk production in some systems in the US may offset that advantage.

\section{Use of Selection Indices}

An economic index that weights predicted genetic gains in certain traits by their economic value can assist simultaneous progress in economically important traits (Hazel, 1943; Horan et al., 2005a) and thereby minimize potentially adverse effects when negative associations exist among traits of interest. The economic index Net Merit \$ (NM\$; formerly Predicted Difference $\$$ ), created by the USDA in 1971, initially included only 2 traits: milk yield (52\% weighting) and fat ( $48 \%$ weighting). As more information became available, the index was changed and improved to add protein (1976), productive life (1994), SCS (1994), udder composite (2000), feet/legs composite (2000), body size composite (2000), daughter pregnancy rate (2003), and calving

Table 3. Performance of daughters of New Zealand (NZ) Holstein or Holstein-Friesian sires in the United States compared with daughters of all other Holstein sires, by parity (from Norman et al., 2006)

\begin{tabular}{lcccc}
\hline Group & SCS & Days open & Milk $(\mathrm{kg})$ & Protein $(\mathrm{kg})$ \\
\hline First-parity NZ daughters & $+0.22^{* * *}$ & $-7^{*}$ & $-481^{* * *}$ & $-5^{* *}$ \\
Spring-calving systems only & $+0.24^{*}$ & -6 & $-351^{* * *}$ & -4.1 \\
Second parity NZ daughters & +0.10 & $-8^{*}$ & $-572^{* * *}$ & $-6.8^{* * *}$ \\
Spring-calving systems only & +0.16 & -1 & $-538^{* * *}$ & $-8.2^{*}$ \\
Third parity NZ daughters & +0.06 & -2 & $-479^{* * *}$ & -5 \\
Spring-calving systems only & +0.11 & -1 & $-745^{* * *}$ & $-13.2^{* *}$ \\
\hline Difference between NZ daughters and all other bulls' daughters significant at ${ }^{*} P \leq 0.05,{ }^{* *} P \leq 0.01$, and ${ }^{* * *} P$ \\
$\leq 0.001$.
\end{tabular}


ability (2006) (Cole et al., 2010). Of note is the increase in economic weighting of daughter pregnancy rate from $7 \%$ of the index in 2003 to $11 \%$ in 2010 , the increase in weighting of productive life from $20 \%$ in 1994 to $22 \%$ in 2010, and the decreased weighting of milk volume, from $52 \%$ of the index in 1971 to $0 \%$ emphasis today (Cole et al., 2010). The more recent emphasis on fitness traits $(65 \%)$ compared with production traits (35\%) is in response to unfavorable trends in fitness traits. However, because of differing milk markets within the US, the USDA (Cole et al., 2010) also calculates net merit estimates for cheese yield (CM\$), which includes more emphasis on protein yield and negative weighting on fluid milk. Negative weighting on fluid milk was also used in indices of several countries in which marketing of milk solids is emphasized (VanRaden, 2004). A third index is calculated for fluid milk (FM\$), which reduces emphasis on protein and places more value on fluid milk and fat production.

Similar economically weighted selection indices are used in several countries, including Breeding Worth in NZ (DairyNZ, 2013b) and the Economic Breeding Index (EBI) in IE (Berry et al., 2007), both of which emphasize milk solids and negative weighting on fluid milk similar to the $\mathrm{CM} \$$ used in the US. In the EBI, only $42 \%$ of the emphasis is on production traits $(13 \%$ milk, $5 \%$ fat, $24 \%$ protein) and $58 \%$ of the emphasis is on functional traits (37\% fertility, $8 \%$ calving, $8 \%$ beef, and $5 \%$ health), and a high EBI relates to high milk solids production and increased longevity (Berry et al., 2007).

Production traits accounted for most of the weighting for breeding indices in Israel (80\%) and Japan (75\%) but only 34\% in Denmark, 29\% in Sweden (VanRaden, 2004; Miglior et al., 2005), and just $28 \%$ in Norway by 2009 (Geno, 2010), with the latter 3 countries including emphasis on health, fertility, and longevity (VanRaden, 2004; Geno, 2010). Because of concerns about declining fertility and productive life in dairy cattle, measures of fertility and longevity were included in selection indices for most countries by 2003 (VanRaden, 2004; Miglior et al., 2005).

Recent Irish studies by Cummins et al. (2012a,b) compared HO cows grouped by genetic merit for fertility (good vs. poor) but with similar genetic merit for milk yield and components within a pasture-based, spring-calving system. They reported that cows with higher genetic merit for fertility maintained slightly greater BCS, had $4.3 \%$ greater daily milk yield (19.5 $\mathrm{kg} / \mathrm{d}$ vs. $18.7 \mathrm{~kg} / \mathrm{d}$ ) but had $28.2 \mathrm{~d}$ less from calving to conception, and required 1.05 fewer services per conception with no apparent differences in pasture intake, BW, or energy balance (Cummins et al., 2012a). Also, cows with higher genetic merit for fertility tended to have fewer follicular waves, $4.1 \mathrm{~d}$ shorter estrous cycles, larger preovulatory follicle diameters, more activity during estrus, larger corpora lutea, and $34 \%$ greater circulating progesterone than cows with poor genetic merit for fertility (Cummins et al., 2012b). Such results provide evidence that there is opportunity to improve reproduction within breeds with the use of genetic selection.

\section{Is a Pasture-Based Selection Index Needed?}

The economic basis of current US selection indices depends upon the producing ability and longevity of dairy cattle for increasing lifetime milk production to achieve high economic return per cow. Pasture-based dairy producers are also interested in economic return but tend to emphasize economics and milk production per unit of land rather than per cow. Genetic selection on pasture-based dairies ultimately depends upon the management type of the grazing dairy and the manager's goals for genetic progress. Visscher et al. (1994) assessed economic weights for traits in Australian pasture-based genetic selection indices and recommended that milk yield, fat yield, protein yield, mature BW, and longevity be considered as breeding objectives. With those objectives in mind, construction of one or more pasture-based selection indices should rely on economic weights for specific markets of interest depending upon premiums paid for milk volume or components. Also of consideration, particularly if a dairy intends to calve seasonally, is the evaluation of both male and female fertility traits, as recommended by Weigel et al. (1999).

The continued development of resources such as genomic testing should lead to earlier and improved prediction of expected performance across multiple traits (Wiggans et al., 2011; Weigel et al., 2012). Genomic testing may be particularly useful for improvement in traits that are lower in heritability, such as those associated with reproduction and health. With more advances in data systems, it may be feasible and useful to have software programs developed that would allow producers or dairy consultants to interactively add or reduce emphases on various traits of interest. An economically based selection index could be used to identify groups of bulls to consider and each farm could choose sires within those groups that best suit their own goals.

\section{ASPECTS OF PASTURE SYSTEMS}

\section{Supplementation Level and BCS}

Managers of pasture-based dairy systems choose varying levels of concentrate supplementation for their 
cows depending upon their personal preference, cost of concentrates, and length of grazing seasons. Shorter growing seasons, as seen in the northern US, require growing, harvesting, and storing forage or purchasing forages for use during the nongrazing season. Good pasture management is essential for the bottom line of any pasture-based dairy but graziers may choose to add concentrates to increase milk production, especially for cows that cannot reach their genetic potential on pasture alone. Also, use of concentrates or other supplements can allow increased stocking rates and increased productivity per unit of land (Macdonald et al., 2008a; Baudracco et al., 2011; Macoon et al., 2011; McCarthy et al., 2012; Vibart et al., 2012). Insufficient DMI of pasture is certainly a limiting factor to milk production by high-producing dairy cows, as reviewed by Bargo et al. (2003). They noted that "milk production [of grazing cows] increases linearly as the amount of concentrate increases from 1.2 to $10 \mathrm{~kg} \mathrm{DM} /$ day, with an overall milk response of $1 \mathrm{~kg}$ milk/ $\mathrm{kg}$ concentrate." However, for each kilogram of supplemental concentrate, grazing time decreased $12 \mathrm{~min} / \mathrm{d}$ (Bargo et al., 2003) and, at higher rates of supplementation, incremental milk yield responses are expected to be less (Vance et al., 2013).

Milk production per cow is typically lower in grazing herds with minimal to moderate supplementation compared with herds consuming a TMR in barn confinement in North America (Kolver and Muller, 1998; Soriano et al., 2001; White et al., 2002; Boettcher et al., 2003; Fontaneli et al., 2005). At relatively high levels of supplementation such as $1 \mathrm{~kg}$ of concentrate for each $3 \mathrm{~kg}$ of milk, high-yielding $\mathrm{HO}$ cows in Canada in intensively managed grazing systems had similar milk yield over 2 yr compared with confined, TMR-fed HO (Fredeen et al., 2002). However, this may be a function of the short grazing season as well as the difference in diet composition. Substituting part of the TMR of HO cattle with high-quality pasture did not adversely affect milk production in North Carolina with up to $34 \%$ of the total diet as annual ryegrass pasture (Vibart, 2006) or in Louisiana by allowing early- to mid-lactation cows $\sim 2.7 \mathrm{~kg}$ of $\mathrm{DM} /$ day of oat and ryegrass pasture in late fall (McCormick et al., 2011). Therefore, moderate to high supplementation in pasture-based systems or using pasture as a supplement to TMR can be used to maintain high levels of milk production, especially from cows bred to perform in a TMR feeding system.

High-producing cattle may need time to "learn to graze" before decisions about the efficacy of grazing can be made. For example, mid-lactation HO transitioned from a TMR to grazing either native grasses or a mixed pasture sward plus supplementation had lower production and estimated DMI than expected in a Wisconsin study (Wu et al., 2001), likely in part because the cows were used to a TMR and may not have had time to adapt before the beginning of the grazing experiment. Providing TMR in the pasture rather than in a separate feeding facility could reduce pasture intake: when given the choice of eating TMR indoors or on pasture, late-lactation HO consumed $2.2 \mathrm{~kg} / \mathrm{d}$ more TMR in the pasture (Charlton et al., 2011).

Cows that can maintain a higher BCS may have an advantage in pasture systems because they can draw upon body reserves if feed is limited, resulting in higher total lactation yields of milk solids as well as good fertility (Pryce and Harris, 2006). It has been documented that North American (NA) HO require more supplementation than other strains and breeds to maintain body condition in pasture systems (Roche et al., 2006; Macdonald et al., 2008b).

In a short-term study of high-producing early lactation HO in Pennsylvania (Kolver and Muller, 1998) on a $100 \%$ pasture diet or a $100 \%$ TMR diet, pastured cows had lower daily milk production $(29.6 \mathrm{~kg}$. vs. 44.1 $\mathrm{kg}$ ), weighed $35 \mathrm{~kg}$ less, and averaged 0.5 lower BCS (5-point scale of Wildman et al., 1982) than cows consuming a TMR. Also in Pennsylvania, a 21-wk study by Bargo et al. (2002) reported that HO cows consuming pasture plus concentrate lost BCS $(-0.20)$, cows consuming pasture plus TMR maintained BCS $(+0.01)$, whereas cows consuming a TMR gained BCS $(+0.19)$. Soriano et al. (2001) also observed lower BCS in HO cows on pasture versus cows in TMR-based feeding systems in Virginia.

In Florida, HO cattle grazed on 2 combinations of cool season and warm season pastures with concentrate supplementation had a greater postpartum loss of BW than TMR-fed cattle, and BW remained significantly lower through much of the lactation period (Fontaneli et al., 2005). In that study, confinement-fed cattle also produced more milk but milk composition was similar across treatments.

Both JE and HO cows had lower BCS on pasture than TMR-fed cows, in a 3-yr systems study of seasonally calved pasture-based and confined cattle (Washburn et al., 2002b). Clearly, grazing cattle in systems that derive much of their nutrients from pasture tend to have lower BCS than cattle in TMR-based systems and lower overall milk production. However, in situations where limited amounts of high-quality pasture are fed as a supplement to a TMR, both body condition and milk production can be maintained (Vibart, 2006). For systems in which pasture is used as a supplemental feed to a TMR ration, there is likely less overall energy expenditure for walking and grazing compared with systems in which pasture makes up most the diet.

Pryce and Harris (2006) estimated the heritability of BCS in NZ first-parity cows to be between 0.25 and 
0.27 among NZ HF, NA HO, JE, and crossbreds. Genetic correlations of BCS with 21-d submission rate and 42-d calving rate were 0.497 and 0.433 , respectively. Those relationships are potentially useful for seasonalcalving dairy herds interested in improving both BCS and reproductive performance.

Once-a-day $(1 \times)$ milking has been used selectively in pasture-based herds to allow thinner cows to regain body condition before the end of lactation and as a lifestyle choice to allow time for other activities. Milking $1 \times$ has no adverse effect on animal welfare or total time spent grazing (Tucker et al., 2007) but does reduce milk yields (Clark et al., 2006; Hickson et al., 2006). Clark et al. (2006) reported a significant interaction in NZ HF compared with JE in that HF were more negatively affected by $1 \times$ milking (milk yield, $82.3 \%$ of $2 \times$; milk solids, $83.7 \%$ of $2 \times$ ) than JE (milk yield, $91.1 \%$ of $2 \times$; milk solids, $93.7 \%$ of $2 \times$ ) for yields per hectare. Cows milked $1 \times$ conceived $3 \mathrm{~d}$ earlier, had $5 \mathrm{~d}$ less from calving to conception, and needed $11 \%$ fewer synchronization treatments for breeding (Clark et al., 2006). Selection for cows that perform well under $1 \times$ management could improve longer term performance, which may be useful in pasture-based systems using less supplementation.

\section{Reproduction in Pasture Systems}

Selection for reproductive traits in any management system is a challenge because of low heritability estimates and high variation of environmental effects (Berglund, 2008). Genetic selection for milk production can affect reproductive traits, however, as evidenced by the consistent genetic improvements in milk yield in NA HO accompanied by a decline in reproductive performance (Pryce and Veerkamp, 2001). For example, average days open increased $37 \mathrm{~d}$ across a 40 -yr period (Norman et al., 2006), the majority of that increase occurring in the mid-1980s through the 1990s (Washburn et al., 2002a).

The InCalf project in Australia revealed that from 2000 to 2009 , median 6 -wk pregnancy rates among 30 herds declined by about 1 percentage point per year (Morton, 2011). A review by Dillon et al. (2006) documented that selection for increased milk production over a 14-yr period (1990 to 2003) in IE resulted in increased milk production per cow but only $41 \%$ of the potential improvement in farm profit was achieved because of associated impaired reproductive performance.

Milk production has adverse genetic correlations with calving interval, days open, days to first service, and conception rate at first service, as reviewed by Pryce et al. (2004). In addition, genetic recessive haplotypes have been associated with embryonic mortality in some breeds (VanRaden et al., 2011). Although cows selected for high production often have decreased fertility, this may be more associated with physiological adaptations to increased milk production (Lucy, 2001; Pryce et al., 2004) rather than because of direct genetic effects. However, improved management can result in higher fertility in higher-producing herds.

Timing of Puberty and Age at First Calving. Timing of puberty is a potentially useful metric for predicting reproductive success and is particularly relevant for seasonal breeding systems. At puberty, HO heifers of 1990s genetics (HO90) were $20 \mathrm{~d}$ older and 20 $\mathrm{kg}$ heavier than HF heifers of 1990s genetics (HF90), which were $25 \mathrm{~d}$ older and $25 \mathrm{~kg}$ heavier than HF heifers of 1970s genetics (HF70) in an NZ study (Macdonald et al., 2007). By 400 d of age, only $79 \%$ of HO90 heifers had reached puberty compared with $97 \%$ of HF90 heifers. A comparable delay in puberty of heifers with $\mathrm{HO}$ background was observed in a North Carolina study of pasture-based dairy cattle: age at puberty and weight at puberty increased linearly with percentage $\mathrm{HO}$ compared with $\mathrm{JE}$ or various percentages of $\mathrm{HO} \times \mathrm{JE}$ and JE $\times \mathrm{HO}$ crosses (Williams, 2007). In that study, average age at puberty for $\mathrm{HO}$ averaged $404 \mathrm{~d}$, whereas other breed groups with various percentages of JE averaged 20 to $95 \mathrm{~d}$ younger. Delays in puberty for HO or other breeds in pasture-based systems, particularly lower input systems, could affect success in maintaining seasonal breeding and calving.

Age at first calving, though more affected by management than genetics, is also an important metric of reproductive success because of its relationship with age at puberty, timing of first breeding, and ability to maintain seasonal calving. Age at first calving in the US in 2004 for Ayrshires (AY) was highest at 28.3 mo with JE lowest at 24.1 mo. Guernsey (GU) and Brown Swiss (BS) cattle were both just over 27 mo, whereas HO were about 25.5 mo (Hare and Wright, 2006) in the USDA database, which covers all feeding management systems. Age at first insemination, which is related to age at first calving, has a moderate maternal heritability of 0.134 in Canadian HO (Jamrozik et al., 2005) and could be incorporated into a selection index for seasonal herds.

Days Open and Calving Interval. Major dairy breeds in the US have a wide range of average days open, from $127 \mathrm{~d}$ for JE to $151 \mathrm{~d}$ for GU (Figure 1). Calving interval also varies among dairy breeds in both the US and France, with HO generally having longer calving intervals (Figure 1). In France, intervals from calving to first insemination are longer in $\mathrm{HO}$ cows $(88$ d) than in Montbéliarde (MB) cows (75 d) or Nor- 
mande (NM) cows ( $\sim 77$ d; Barbat et al., 2010). During the last decade, MB and NM cows have maintained relatively constant calving intervals of about 386 and $384 \mathrm{~d}$, respectively, whereas average calving intervals in French HO cows increased to 408 d by 2006, an increase of $13 \mathrm{~d}$ from $10 \mathrm{yr}$ earlier (Barbat et al., 2010). Those advantages in shorter calving intervals were evident for $\mathrm{MB}$ and NM, even with longer gestation lengths than for HO (Barbat et al., 2010). Schaeffer et al. (2011) noted that crosses of Swedish Red (SR) or Norwegian Red (NR) cattle with HO had shorter gestation lengths than pure $\mathrm{HO}$ or crosses with BS. Longer gestation lengths (Norman et al., 2009) could contribute to longer calving intervals for breeds such as GU ( +3.2 to 7.0 d) and BS (+5.6 to $9.4 \mathrm{~d})$ compared with AY, milking shorthorn, JE, and HO cattle.

Therefore, age at first calving, gestation length, and calving intervals as indicators of earlier puberty and reproductive efficiency within and among breeds are relevant considerations for seasonal breeding programs. Although each of those factors is affected by environment and management decisions, breed differences are indicative of potential genetic differences for which selection pressure could be applied.

Managing for Seasonal Calving. It is important that cows cycle soon after calving and have high fertil- ity to achieve high pregnancy rates in short periods after the start of mating to maintain calving intervals close to 365 d. For example, with a $90 \%$ submission rate (most animals cyclic at start of breeding) and $60 \%$ conception rate, $54 \%$ of the herd would be expected to conceive within the first $3 \mathrm{wk}$ and $90 \%$ of cows would conceive within a 9-wk breeding season. However, with a submission rate of just $70 \%$ and conception rate of only $36 \%$, then only $25 \%$ of cows would conceive in 3 wk, $58 \%$ would be pregnant at 9 wk, and only $74 \%$ would be expected to be pregnant after 14 wk of breeding. Note that the example used for lower reproductive efficiency is well above average for US nonpastured, year-round calving herds but would be unacceptable for pasture-based herds with seasonal calving.

Timing of the calving season can affect management and profitability. An evaluation of the Moorepark dairy system in IE established that a calving season matched to forage growth (February to April) was more profitable than beginning the calving season even 1 mo earlier (Shalloo et al., 2004).

Because of the importance of high pregnancy rates for seasonal calving, intervention with hormonal therapy can increase the proportion of cows that calve early in the breeding system. Estrous synchronization using a controlled intravaginal drug insert containing

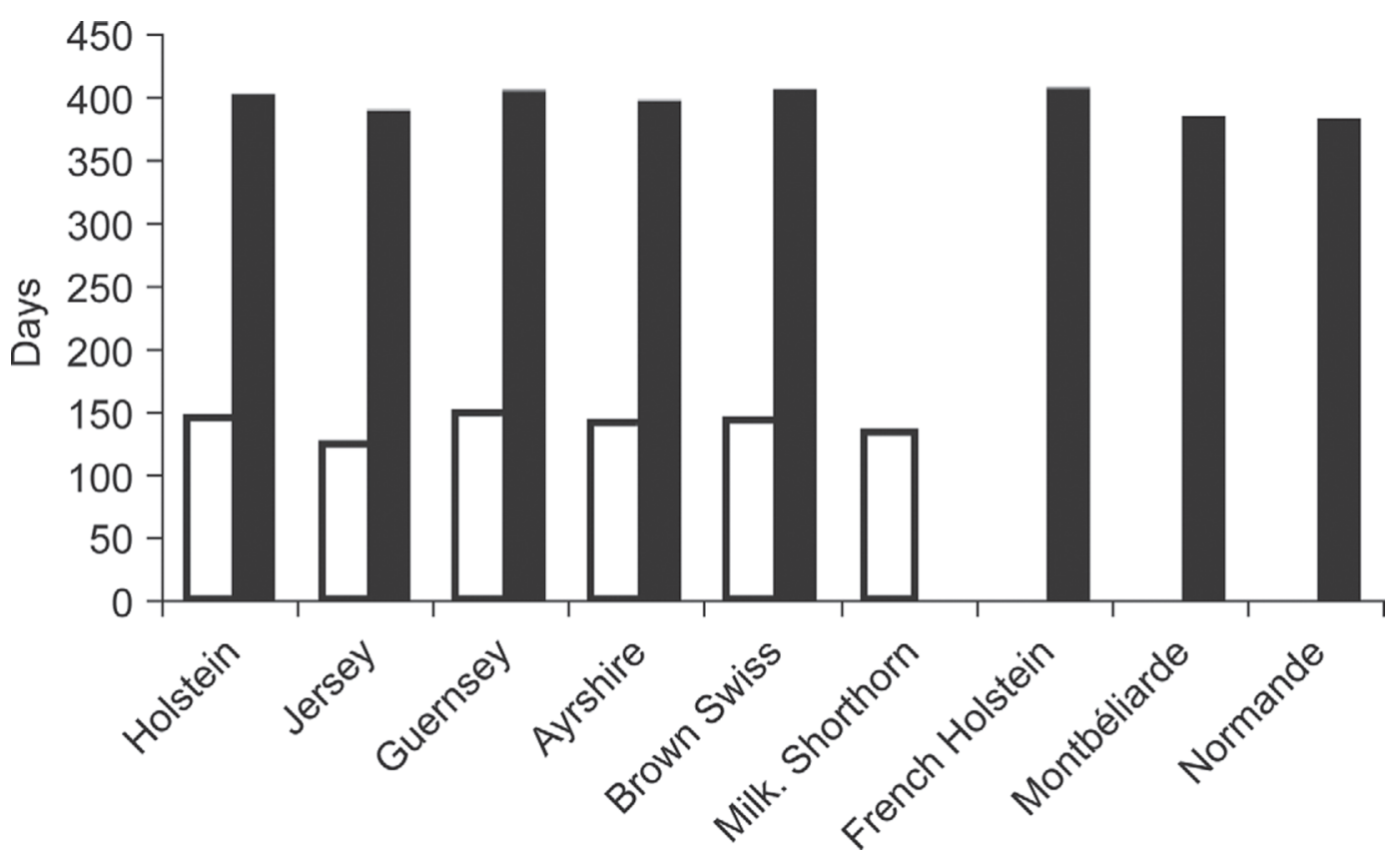

Figure 1. Average days open (white bars) and calving intervals (black bars) for several American and French dairy breeds. Values for French Holstein, Montbéliarde, and Normande are from France (Barbat et al., 2010); mean calving intervals for the other breeds are from the United States and were restricted from 270 to $650 \mathrm{~d}$ in the analysis (Hare and Wright, 2006) and all other data are from the United States assuming a voluntary waiting period of $50 \mathrm{~d}$ (Norman et al., 2006). Standard deviations for calving intervals (Hare and Wright, 2006) ranged from 58.3 d for Ayrshire to $65.8 \mathrm{~d}$ for Holstein. 
progesterone as well as injections of $\mathrm{GnRH}$ and $\mathrm{PGF}_{2 \alpha}$ was more effective at getting Irish pasture-based dairy cows pregnant than breeding based on observed heats alone (Herlihy et al., 2011, 2013). However, estrous synchronization had no effect on the overall pregnancy rate in seasonal-calving grazing herds in NZ by the end of the breeding season (McDougall and Compton, 2005).

For situations in which year-round milk production is desired, efficiencies in animal management might be gained by having 2 seasonal-calving periods. However, from available financial data on commercial pasturebased dairy farms in the US, there may not be a clear economic advantage for use of a seasonal-calving system (Kriegl and McNair, 2005).

\section{BREEDS, STRAINS, AND CROSSBRED COWS FOR PASTURE-BASED DAIRY SYSTEMS}

\section{Strains of $\mathrm{HO}$ or HF}

Comparing strains of $\mathrm{HO}$ or $\mathrm{HF}$ on different continents and environments is of interest as divergence in selection results in the formation of differentially adapted cows within the same breed. Differences in strains of $\mathrm{HO}$ or HF can significantly affect their utility in a seasonal pasture-based system.

Increased proportions of $\mathrm{HO}$ genetics over $14 \mathrm{yr}$ in IE resulted in increased milk production per cow, lower BCS, and a greater production response to concentrates, but resulted in reduced fertility and survival (Dillon et al., 2006). A decline in fertility was also noted in NZ as the percentage of $\mathrm{HO}$ genetics in NZ increased from $2 \%$ in the 1980 s to $38 \%$ by 2000 (Harris and Kolver, 2001). However, when adjusted for percentage of HO genetics and genetic merit for milk yield, spring-calving Irish $\mathrm{HO} / \mathrm{HF}$ herds had a positive relationship between reproductive performance and milk yield (Buckley et al., 2003). In that study, reproductive efficiency was maximized when cows maintained a BCS of $\geq 2.75$ on a 5 -point scale.

New Zealand HF cows of 1990 high genetic merit (HF90) averaging $\sim 24 \%$ NA HO genetics, NZ HF cows ( $\sim 7 \%$ NA HO genetics) of 1970 (HF70) high genetic merit, and NA HO cows ( $>90 \%$ NA HO genetics) of 1990 high genetic merit (HO90) were examined in NZ seasonal-calving grazing systems in a 3 -yr study by Macdonald et al. (2008b). The experiment showed the progress of the NZ HF in milk yield $(+16 \%)$ and milk solids $(+23 \%)$ per cow in pasture-based systems from 1970 to 1990 . The NA HO cows had the genetic potential to perform as well as the NZ cows, but required greater amounts of supplement than is normally provided on NZ dairies because they lost more body condition after calving and remained thin longer than NZ HF cows. In related work, concentrate feeding in the study of Roche et al. (2006) reduced the time from calving to nadir BCS and reduced the extent of body condition loss during lactation. North American HO90 cows did produce more milk per year but had a greater proportion of infected udder quarters than HF90 cows at $>6$ t of DM pasture allowance per cow per year (Macdonald et al., 2008b). They also observed higher pregnancy rates for both strains of NZ HF (69\%) compared with HO90 (54\%) within the first 6 wk of the breeding season. The HO90 cows did start cycling sooner after calving than HF70 and HF90 strains, but HO90 cows had 3-d-longer gestations than NZ HF (Macdonald et al., 2008b). Considering both production and reproduction in that system, HF90 cows were projected to have an economic advantage over both the HF70 and HO90 strains.

Horan et al. (2005a) compared 3 strains of $\mathrm{HO}$ and HF cows (high-producing NA HO, high-durability NA $\mathrm{HO}$, and NZ HF) in 3 different grazing systems in IE over a 3 -yr period. They documented that cows receiving concentrates in a rotational grazing system had significantly greater milk protein, lactose, and peak milk production than cows in a high-stocking-rate or a high-grass-allowance grazing system. Across strains, greater production per cow occurred with high pasture allowance versus high stocking rate, but an interaction occurred in that NA HO were most adversely affected at the higher stocking rate (Horan et al., 2005a). In a companion study, NZ HF cows averaged a 6-d-shorter gestation than either high-producing or high-durability NA HO (Horan et al., 2005b).

An Irish study (Snijders et al., 2001) compared highgenetic-merit $\mathrm{HF}$ cows $(+475 \mathrm{~kg}$ predicted difference milk) to lower genetic merit HF cows $(+140 \mathrm{~kg}$ predicted difference milk) with varying levels of supplementation for cows grazing perennial ryegrass pasture. As expected, milk production was higher for the highgenetic-merit cows but those cows also had lower conception rates, greater BCS loss, and required 0.76 more services (2.67 vs. 1.91) per conception (Snijders et al., 2001). Differing amounts of supplementation provided did not affect reproductive performance, which was also seen in a comparison of Australian HF cows fed at 2 supplementation levels on pasture (Pedernera et al., 2008). Cows fed to produce $9,000 \mathrm{~L}$ of milk/cow and lactation had more mastitis but no difference in days to first luteal activity, days to first service, or days open compared with cows fed to produce $6,000 \mathrm{~L} /$ cow per lactation (Pedernera et al., 2008).

Outcrosses among strains of HO and HF may also confer advantages in milk yield, protein yield, or fat yield, as observed in Chile (Elzo et al., 2004).

Because milk production is high and reproductive success is low for NA HO in pasture-based systems, ex- 
tending lactations up to 22 mo and calving intervals up to 24 mo can be considered an alternative management strategy (Auldist et al., 2007, 2010; Kolver et al., 2007; Grainger et al., 2009; Butler et al., 2010). In Australia, more than $40 \%$ of NA HO assigned to extended lactations of 22 mo reached that target (Auldist et al., 2007) and production of milk solids from NA HO in NZ was $94 \%$ of that of cows assigned to 10-mo lactations compared with only $79 \%$ from NZ HF cows, resulting in a significant genotype $\times$ environment interaction (Kolver et al., 2007). Grainger et al. (2009) reported only a $2.4 \%$ reduction in annualized yields of milk solids from 22-mo lactations versus 10-mo lactations among HO in Australia. Further, cows with extended lactations gained more body condition and more BW before the end of lactation (Auldist et al., 2007). Holstein cattle undergoing extended lactations had milk composition similar to those with 10-mo lactations but had greater cheese yield (Auldist et al., 2010). Extended lactations can make high-producing $\mathrm{HO}$ feasible in a seasonalcalving, pasture-based system, with potential positive effects on cheese yield and BCS compared with annual calving. In IE, Butler et al. (2010) reported that using 24-mo calving intervals for high-producing cows may have merit compared with culling those cows, but such systems were less profitable than systems with calving at 12 -mo intervals where seasonal production is warranted.

Different strains of $\mathrm{HO}$ or HF can be used to match the pasture-based dairy management style practiced. If a dairy farmer desires to use high-producing $\mathrm{HO}$ in a pasture-based dairy system, consideration should be given to lower reproduction efficiency and the necessity of increased supplementation for the HO to achieve their genetic milk production potential and to maintain sufficient BCS.

\section{Comparisons of HO or HF and JE or Crosses of Those Breeds}

Harris et al. (2000) compared fertility in HO, JE, and their crosses and noted that crossbreeding improved fertility and survival compared with the pure HO genetics. Pryce and Harris (2006) evaluated the breed and heterosis effects of JE, NZ HF, and NA HO in NZ first-parity cows; crosses within the NZ HF and NA HO had the most positive heterosis for BCS compared with the population mean. Conception rates and seasonal pregnancy rates were higher for purebred JE and crossbreds compared with purebred $\mathrm{HO}$ in a North Carolina study by Vibart et al. (2012).

In Northern Ireland, spring-calving groups of $\mathrm{HO}$ cows and $\mathrm{JE} \times \mathrm{HO}$ crossbred cows were compared over 3 yr at 3 levels $(0,2.5$, and $5.0 \mathrm{~kg} / \mathrm{cow} / \mathrm{d})$ of concentrate supplementation while grazing (Vance et al., 2013). Milk production was higher for $\mathrm{HO}$ cows but fat plus protein yields were similar across genetic groups with greater yields from increased rates of concentrate supplementation. They reported fewer days to first estrus, higher conception rates, higher breeding season pregnancy rates, and greater $\mathrm{BCS}$ for $\mathrm{JE} \times \mathrm{HO}$ compared with $\mathrm{HO}$. Feeding system did not affect fertility measures.

In North Carolina, pasture-based JE and HO cattle had lower milk production and lower BCS but had fewer cases of mastitis and similar reproductive efficiency within breed compared with TMR-fed cattle (Washburn et al., 2002b; White et al., 2002). In comparing breeds, HO milked more than JE but had lower BCS, lower fertility, and more mastitis than JE in both pasture and confinement systems (Washburn et al., 2002b; White et al., 2002).

Somewhat conflicting results are reported for the BCS of JE compared with NA HO in a pasture-based system with evaluation in different countries: Prendiville et al. (2009) evaluated production efficiencies among Irish $\mathrm{HO}$ ( $>84 \%$ NA genetics), JE, and JE $\times \mathrm{HO}$ crosses and observed that, similar to Washburn et al. (2002b), JE had higher BCS than HO during lactation. In addition, JE $\times \mathrm{HO}$ had an even higher BCS of 3.00 , with a significant hybrid vigor estimate of 0.16 for BCS. Hybrid vigor was also evident for milk yield, lactose content, solids-corrected milk, milk solids, and BW (Prendiville et al., 2009). In contrast, Pryce and Harris (2006) reported a negative breed effect for BCS for pure JE and NA HO compared with NZ HF, or crosses between either the NA HO or NZ HF strains and JE on NZ dairy farms. In the study of Washburn et al. (2002b), JE cows were provided concentrate supplement similar to $\mathrm{HO}$ and likely had relatively higher concentrate intake compared with energy needs for production and maintenance.

Crossbreeding also may be advantageous for pasture intake per bite and biting rate, as shown by a novel grazing mechanism study by Prendiville et al. (2010). In that study, Irish $\mathrm{HO}, \mathrm{JE} \times \mathrm{HO}$, and $\mathrm{JE}$ cattle were observed while grazing to determine rumination, prehension, and mastication rates. Overall, $\mathrm{HO}$ spent more time ruminating and masticating but, per unit of BW, JE had the greatest duration of rumination and mastication. Crossbred cows had fewer bites per day than either parent breed and had intermediate milk production (Prendiville et al., 2010).

As noted above, crosses between HO and JE generally have advantages in fertility and maintenance of BCS, and are competitive for milk yield compared with purebred cattle in pasture-based systems. 


\section{Other Breeds and Crosses}

Sørensen et al. (2008) reviewed crossbreeding in dairy cattle production systems and noted heterosis advantages for longevity and functional traits leading to improved economics. In that review, they concluded that heterosis for milk production was small and that some traits such as mastitis, calving ease, and calf survival may not be improved in some crossbreeding regimens. Consensus is that systematic crossbreeding involving 3 breeds is optimal to maintain $86 \%$ of $\mathrm{F}_{1}$ heterosis but some 2-breed crossbreeding regimens can be useful with just $67 \%$ of $\mathrm{F}_{1}$ heterosis (Sørensen et al., 2008).

Although crosses of breeds such as NR, MB, and NM with $\mathrm{HO}$ have been used in the US, most data available are from non-pasture-based systems in California (Heins et al., 2006a,b). Very positive effects on fertility were observed for crossbred cows, including fewer days to first service, greater conception rates, fewer days open, and increased survivability in the study of Heins et al. (2006b). Those results likely reflect heterosis for fertility in crossbred cows as well as a breed effect for higher fertility based on data reported for purebred $\mathrm{MB}$ and NM cows compared with pure HO in France (Barbat et al., 2010). Also, addition of NR genetics to a pasture-based dairy could confer advantages in milk quality and reproduction that can be expected based on inclusion of udder health since 1978 and fertility since 1971 in the selection index for NR in Norway (Geno, 2010).

Milk production of NR cows on spring- and fallcalving dairies in Northern Ireland was significantly lower than HF in first- and second-lactation cows, but SCS was lower in NR cows for all measured lactations (Ferris et al., 2012). Also, NR cows consistently had greater first-service conception rates than HF (Ferris et al., 2012).
In Irish studies at Moorepark, Walsh et al. (2007, 2008) compared $\mathrm{HF}, \mathrm{MB}, \mathrm{NM}, \mathrm{NR}, \mathrm{MB} \times \mathrm{HF}$, and $\mathrm{NM} \times \mathrm{HF}$ cattle in a spring-calving, pasture-based system at 2 levels of supplement. Cows in that study receiving $3.8 \mathrm{~kg} / \mathrm{d}$ of concentrate had greater average daily milk yield than cows receiving $1.9 \mathrm{~kg} / \mathrm{d}$ of the same concentrate, regardless of breed. The SCS of the $\mathrm{NR}$ and MB breeds were less than that of HF, whereas $\mathrm{SCS}$ of the $\mathrm{NM}, \mathrm{MB} \times \mathrm{HF}$, and $\mathrm{NM} \times \mathrm{HF}$ breeds were similar to HF. Crossbred cattle had higher BCS, longer postcalving survival, and a higher pregnancy rate than the purebred cattle (Table 4). Walsh et al. (2008) reported on production, BCS, and reproduction over $5 \mathrm{yr}$ for the various breed combinations. Milk yields favored HF for solids-corrected milk, whereas pure MB and NM produced the least, and $\mathrm{NR}, \mathrm{MB} \times \mathrm{HF}$, and $\mathrm{NM} \times \mathrm{HF}$ were intermediate in production. Greatest BCS loss 2 to 8 wk postpartum in the study by Walsh et al. (2008) was observed for NR and HF ( -0.2 BCS units) but NR did maintain greater BCS than HF throughout lactation. The interval from calving to first service was significantly shorter for $\mathrm{NM}, \mathrm{NR}$, and $\mathrm{MB} \times \mathrm{HF}$ compared with HF. Least likely to conceive in this study were the $\mathrm{HF}$, which was a major factor in the shorter herd life of only 1.9 lactations compared with 2.8 to 3.9 lactations for other breed groups (Table 4; Walsh et al., 2008).

Another study of Irish spring-calving dairy cows noted that $\mathrm{HF}$, JE, and $\mathrm{MB}$ cattle and their crosses with NA HO had shorter calving intervals relative to NA HO; breed effects were as follows: HF: $-7.9 \pm 2.2$ d; JE: $-6.9 \pm 4.1 \mathrm{~d}$; MB: $-2.2 \pm 3.4 \mathrm{~d} ; \mathrm{HO} \times \mathrm{HF}:-1.3$ $\pm 0.9 \mathrm{~d} ; \mathrm{HO} \times \mathrm{JE}:-2 \pm 4.8 \mathrm{~d} ; \mathrm{HO} \times \mathrm{MB}:-10.2 \pm 4.2 \mathrm{~d}$ (Penasa et al., 2010). A study in Minnesota comparing $\mathrm{HO}, \mathrm{MB} \times \mathrm{HO}$, and 3 breed crosses of $\mathrm{MB} \times(\mathrm{JE} \times \mathrm{HO})$ reported that crossbred cows had higher survival, firstservice conception, and pregnancy rates as well as 41 fewer days open than HO. In addition, the 3 -way crosses

Table 4. Relative performance of various breeds in a spring-calving, pasture-based system in Ireland ${ }^{1}$

\begin{tabular}{|c|c|c|c|c|c|}
\hline Breed $^{2}$ & $\begin{array}{c}\text { Daily } \\
\text { milk (kg) }\end{array}$ & $\begin{array}{l}\text { Lactation- } \\
\text { average SCC }\end{array}$ & BCS & $\begin{array}{l}\text { Seasonal } \\
\text { pregnancy } \\
\text { rate }(\%)\end{array}$ & $\begin{array}{l}\text { Postcalving } \\
\text { survival }^{3}\end{array}$ \\
\hline $\mathrm{HF}$ & $22.6^{\mathrm{a}}$ & $57,526^{\mathrm{b}}$ & $2.77^{\mathrm{A}}$ & 80 & 1.9 \\
\hline MB & $20.1^{\mathrm{b}}$ & $35,242^{\mathrm{a}}$ & $3.15^{\mathrm{B}}$ & 89 & 2.8 \\
\hline NM & $19.1^{\mathrm{b}}$ & $53,104^{\mathrm{b}}$ & $3.16^{\mathrm{B}}$ & 87 & 2.9 \\
\hline NR & $21.5^{\mathrm{b}}$ & $30,031^{\mathrm{a}}$ & $3.06^{\mathrm{B}}$ & 91 & 3.9 \\
\hline $\mathrm{MB} \times \mathrm{HF}$ & $22^{\mathrm{ab}}$ & $55,826^{\mathrm{b}}$ & $3.00^{\mathrm{B}}$ & 90 & 3.8 \\
\hline $\mathrm{NM} \times \mathrm{HF}$ & $21.4^{\mathrm{b}}$ & $51,021^{\mathrm{b}}$ & $3.00^{\mathrm{B}}$ & 90 & 3.2 \\
\hline
\end{tabular}

$\overline{\mathrm{a}, \mathrm{b}}$ Different lowercase superscripts within column indicate a significant difference $(P<0.05$.

${ }^{\mathrm{A}, \mathrm{B}}$ Different uppercase superscripts within column indicate a significant difference $(P \leq 0.001)$.

${ }^{1}$ Average daily milk and lactation-average SCC are from Walsh et al. (2007); all other data are from Walsh et al. (2008).

${ }^{2} \mathrm{HF}=$ Holstein-Friesian $; \mathrm{MB}=$ Montbéliarde; $\mathrm{NM}=$ Normande; $\mathrm{NR}=$ Norwegian Red $\mathrm{MB} \times \mathrm{HF}=$ crosses of $\mathrm{MB}$ and $\mathrm{HF} ; \mathrm{NM} \times \mathrm{HF}=$ crosses of $\mathrm{NM}$ and $\mathrm{HF}$.

${ }^{3}$ Number of lactations in the herd after first calving. 
in that study had fat-plus-protein production similar to that of the HO cows in a pasture-based system (Hazel et al., 2014).

Use of NR, MB, and NM for crossbreeding in pasturebased systems in the US would likely improve reproduction, BCS, and longevity, and one or more of those European breeds might be a good complement to HO and JE for 3-breed rotational crossbreeding strategies. The University of Minnesota is currently conducting pasture-based research with crosses involving $\mathrm{HO}, \mathrm{MB}$, and SR, as well as crosses among HO, JE, NM, and SR at the West Central Research Station in Morris, Minnesota (B. J. Heins, personal communication); North Carolina State University is initiating studies involving crosses of HO, JE, and NR at the Center for Environmental Farming Systems in Goldsboro, North Carolina.

\section{ECONOMIC EVALUATIONS OF PASTURE SYSTEMS}

Various studies have established the economic competitiveness of pasture-based systems compared with confinement systems using various breeds and breed crosses. Profitability of simulated grazing dairy systems increases with increasing amounts of supplemental feeding, but profitability is incrementally smaller at higher supplementation levels (Soder and Rotz, 2001). With feed prices varying across time, optimum levels of feed supplementation might also be expected to vary. Moderately intensive grazing practices with at least $15 \%$ of forage from grazing can increase profitability compared with extensive grazing practices (Hanson et al., 1998). Even with less intensive grazing, cows with pasture access in addition to TMR had higher income over feed cost (IOFC) than cows consuming only TMR in Virginia (Soriano et al., 2001).

Dairy grazing systems have the potential to be economically competitive and possibly more profitable than confinement systems (Kriegl and McNair, 2005), in part due to lower capital investment, less labor, and simpler manure management needs (White et al., 2002) as well as lower feed costs (Fontaneli et al., 2005). In Pennsylvania, a model developed from data on an 80ha farm projected an economic advantage for a grazing system plus concentrate versus a dry lot feeding system (Parker et al., 1992). Other studies have reported similar IOFC for grazing and confined cattle in North Carolina (White et al., 2002) and Florida (Fontaneli et al., 2005). Cows on intensively managed pastures were more profitable than confined cows over 2 yr in Atlantic Canada (Fredeen et al., 2002). In North Carolina, HO had higher IOFC than JE (White et al., 2002) but that economic advantage was at least partially offset by higher fertility and improved udder health among the JE (Washburn et al., 2002b). Also, because of smaller
BW, stocking rates could be higher for JE compared with HO.

Stocking rates can also affect the economics of dairy grazing systems. In a multi-year study of HF in grazing systems in NZ, Macdonald et al. (2011) reported data on 5 different stocking rates ranging from 2.2 to 4.3 cows/ha and examined the profitability relating to a milk solids-based market or a fluid milk market. In a solids-based market, profitability per hectare was optimized at an intermediate stocking rate, whereas in a fluid market, profitability per hectare increased linearly with stocking rate. In a fluid milk market in North Carolina, Vibart et al. (2012) noted higher productivity and greater IOFC when pastures were stocked at 3.3 versus 2.2 cows/ha.

Lopez-Villalobos et al. (2000a) established a model for NZ dairymen to evaluate the economic implications of maintaining $\mathrm{AY}, \mathrm{HF}$, and $\mathrm{JE}$ as pure breeds compared with various 2- or 3-breed rotational crossbreeding regimens using those breeds. In their model, increasing HF genetics in the dairy population resulted in the highest net income for the industry, whereas straight breeding and 2-breed rotational $\mathrm{HF} \times \mathrm{JE}$ systems yielded only slightly less net income. However, if the marginal price of butter produced above base levels was the same as the average base butter value, then increasing JE genetics in the population would be the most profitable and $\mathrm{HF} \times \mathrm{JE}$ would be nearly as profitable (Lopez-Villalobos et al., 2000a).

Those data suggest that the most successful breeds and breed combinations will ultimately depend upon both the pasture system and value of components in the milk market. Lopez-Villalobos et al. (2000b) also reported that 2- and 3-breed rotational breeding systems can be more profitable per hectare than straight HF breeding, using a model that included milk income, beef income, and production costs among other modeling factors. Using net income $\mathrm{NZ} \$ / \mathrm{ha} / \mathrm{yr}$, relative profitabilities for various breed groups were as follows: $\mathrm{HF} \times \mathrm{JE}=127 \% ; \mathrm{HF} \times \mathrm{AY}=108 \% ; \mathrm{JE} \times \mathrm{AY}=117 \%$; $\mathrm{HF} \times \mathrm{JE} \times \mathrm{AY}=124 \%$; and pure $\mathrm{JE}=108 \%$ as profitable as pure $\mathrm{HF}$ at $100 \%$. The theoretical herd was grazed on ryegrass-clover pasture for the entire year and calved in spring (Lopez-Villalobos et al., 2000b). Heterosis and the effect of JE genetics on milk solids increased profitability in that modeled system.

Multiple dairy graziers in the US have described the growth in equity realized by lower cow turnover and improved reproductive efficiency that they have experienced in pasture-based dairy systems (former Prograsstinators Grazing Group, personal communication). Such efficiencies provide for internal growth such that new pasture-based dairy units can often be stocked without purchase of animals from outside. 


\section{RECOMMENDATIONS FOR SPECIFIC PASTURE-BASED SYSTEMS}

From the presented literature, pasture-based dairy farmers have many different options for genetic selection depending upon goals for their herds. Along with genetic selection both within and across breeds to meet specific goals, good management of animals and pastures is still essential. In situations where supplemental feeds are expensive or otherwise undesirable for specific markets, lower stocking rates and careful pasture management may be the desired option. However, using higher stocking rates (3.3 to 5.0 versus 2.2 to 2.5 cows/ha) plus increased supplementation has multiple benefits: greater IOFC (Vibart et al., 2012), milk production (Macdonald et al., 2008a; Macoon et al., 2011; Baudracco et al., 2011; Vibart et al., 2012), and pasture production (Macdonald et al., 2008a) per hectare in pasture-based dairy systems without negative effects on reproductive performance (Macdonald et al., 2008a; Baudracco et al., 2011; McCarthy et al., 2012). Higher stocking rate coupled with careful management can increase profitability of pasture-based dairy systems using various breeds of cattle.

We suggest that it is very important for dairy graziers to participate in production and financial recordkeeping systems. Regardless of breeds used by dairy graziers, it is important that records be kept on the dairy to contribute to the evaluations of genotypic potential and phenotypic performance in pasture-based systems. Contribution of this information will provide benchmarks for future evaluations of pasture-based dairy systems.

In the various grazing system scenarios described below, the use of a specific selection index should be based on the available market but each should include an appropriate balanced approach to production and fitness traits.

\section{High Supplementation, Nonseasonal Calving, Short or Long Growing Season}

In a situation where a grazier wants to maximize fluid milk production and maintain year-round production, NA HO could be a desirable choice because of their high potential milk production. With year-round calving, expected lower fertility of NA HO compared with other breeds could be tolerated. With high supplementation and limited pasture allowances, grazing could be restricted to cooler times of the day in hotter environments to minimize heat stress. Many other breeds and crosses could also do well in such a system assuming they can produce well without gaining excessive body condition. In North Carolina, herds of pure JE have also produced very well with high levels of supplementation during relatively long grazing seasons (S. P. Washburn, personal observation).

\section{Low Supplementation, Nonseasonal Calving, Short Growing Season}

Managing cattle with these management and climatic factors is more difficult than the other situations mentioned here because, although the grazier intends to use little supplementation, a short growing season coupled with year-round calving may not meet nutritional needs of the cattle for much of the time. This system would require growing or purchasing large amounts of relatively high quality forage. Such costs and expected lower milk production make this scenario less economically feasible. Any low input system such as this would likely require breeds and crosses that produce at low to moderate levels and are able to maintain body condition in the absence of concentrates.

\section{Low Supplementation, Nonseasonal Calving, Long Growing Season}

When a grazier wants to use minimal supplementation, calve year-round, and has the benefit of a long growing season, a wide range of breeds may be suitable with the exception of a very high producing breed such as NA HO. This system is more flexible than other lowsupplementation systems because year-round calving allows graziers to effectively use breeds and crosses less suitable for seasonal breeding. For example, although AY, GU, and BS are older at first calving and have relatively long calving intervals, they could be used in this grazing system. Breeds such as NM and NR might also fit in this system. Emphasis in the breeding system should be placed on functional traits (feet and legs, longevity, udder, moderate body size, calving ability) to ensure hardiness in a pasture system as well as on milk and component production.

\section{Low Supplementation, Seasonal Calving, Short or Long Growing Season}

The use of minimal supplementation coupled with seasonal calving requires cows that are reproductively efficient and adapted to obtain most of their nutritional needs from pasture. Reproductive efficiency should be a primary focus in this system, and cattle that have been selected for efficiency in primarily pasture-based systems, such as NZ HF, would perform well in this system. Pure JE cattle would also be expected to perform reasonably well because of their reproductive efficiency, and crossbreds using JE or NZ HF as well 
as various crosses with NR, SR, NM, and MB would combine reproductive efficiency, grazing performance, and longevity.

\section{Moderate to High Supplementation, Seasonal Calving, Short or Long Growing Season}

The use of moderate to high supplementation coupled with seasonal calving still requires cows that are reproductively efficient but allows flexibility for increasing stocking rates while allowing for significant use of pasture for the duration of the growing season. Available use of supplementation should allow for increased nutrition in early lactation to increase peak production as well as later in lactation to extend the grazing season. The breeds discussed above with expected high fertility could work well in this system with amounts of supplementation adjusted as needed based on pasture availability and changes in body condition. Crosses involving NA HO, AY, GU, and BS would probably also perform well in this system because of hybrid vigor for fertility traits even if the pure breeds were not as good a fit.

\section{SUMMARY, CONCLUSIONS, AND IMPLICATIONS}

Evaluation of pasture-based dairy systems is challenging because of the diversity of practices and constraints that define those systems. It is near impossible to evaluate all combinations of dairy genetics (breeds and breed strains), grazing systems, supplemental feeding options, and breeding strategies in systems research. Therefore, collective knowledge from various studies can be used to infer expected responses for other situations or constraints. As more data from ongoing crossbreeding studies become available and data from commercial use of crossbreeding are accumulated, greater insights on the merits and concerns with crossbreeding can be ascertained. Lactating dairy cows do respond to increasing supplemental feeds but responses are not always consistent across genetic groups or environments, thereby affecting the optimal economic approach. In many studies, measures of fertility were not affected by differences in stocking rate or levels of supplementation. Evaluation of individual traits of economic importance allows for weighting of those traits into a selection index. Fitness traits such as measures of fertility, udder health, and productive life have become more important relative to production traits in various selection indices around the world. Principles of selection are similar across a variety of pasture-based and confinement systems but optimal breeds, breed strains, and selection strategies can differ based on varying management constraints and objectives. Although the relative importance of specific traits within a pasturebased system differ from those for confinement systems, evidence to support completely different selection indices is sparse. Further development of genomic tools may lead to more precise selection of dairy animals most suited for particular management systems. Many breeds and breed combinations are used on dairy grazing farms in the US. However, some breeds have small populations of animals from which to select and data may be lacking on traits of economic importance. Dairy graziers should plan to use a breeding system compatible with their farm business goals.

Pasture-based systems have received renewed interest in the US within the past $20 \mathrm{yr}$. Rising energy costs, higher concentrate prices, and large investments in equipment and facilities for confinement systems have driven such increased interest. Such pasture systems are quite variable and include many levels of supplementation and breed combinations. Use of crossbreeding in pasture-based systems is common and is expected to continue. A crossbreeding system that incorporates high-fertility breeds and high-fertility animals within breed could be an advantage, particularly in seasonally calving herds. Seasonal dairy graziers in the US have indicated potential for higher returns on investment and growth in equity realized by having improved reproductive efficiency in seasonal pasture-based dairy systems. Therefore, new pasture-based dairy units can often be stocked from internal growth without purchase of additional animals.

\section{ACKNOWLEDGMENTS}

On behalf of dairy graziers everywhere, we appreciate the opportunity to provide this review. We appreciate financial support from the USDA Southern Region Sustainable Agriculture Research and Education program as well as from the Agricultural Research Service within the College of Agriculture and Life Sciences at North Carolina State University (Raleigh).

\section{REFERENCES}

Auldist, M. J., C. Grainger, A. V. Houlihan, J. J. Mayes, and R. P. W. Williams. 2010. Composition, coagulation properties, and cheesemaking potential of milk from cows undergoing extended lactations in a pasture-based dairying system. J. Dairy Sci. 93:1401-1411.

Auldist, M. J., G. O'Brien, D. Cole, K. L. Macmillan, and C. Grainger. 2007. Effects of varying lactation length on milk production capacity of cows in pasture-based dairying systems. J. Dairy Sci. 90:3234-3241.

Barbat, A., P. L. Mézec, V. Ducrocq, S. Mattalia, S. Fritz, D. Boichard, C. Ponsart, and P. Humblot. 2010. Female fertility in French dairy breeds: Current situation and strategies for improvement. J. Reprod. Dev. 56:S15-S21.

Bargo, F., L. D. Muller, J. E. Delahoy, and T. W. Cassidy. 2002. Performance of high producing dairy cows with three different feeding 
systems combining pasture and total mixed rations. J. Dairy Sci. 85:2948-2963.

Bargo, F., L. D. Muller, E. S. Kolver, and J. E. Delahoy. 2003. Invited review: Production and digestion of supplemented dairy cows on pasture. J. Dairy Sci. 86:1-42.

Baudracco, J., N. Lopez-Villalobos, L. A. Romero, D. Scandolo, M. Maciel, E. A. Comeron, C. W. Holmes, and T. N. Barry. 2011. Effects of stocking rate on pasture production, milk production and reproduction of supplemented crossbred Holstein-Jersey dairy cows grazing lucerne pasture. Anim. Feed Sci. Technol. 168:131-143.

Berglund, B. 2008. Genetic improvement of dairy cow reproductive performance. Reprod. Domest. Anim. 43(Suppl. 2):89-95.

Berman, A. 2011. Invited review: Are adaptations present to support dairy cattle productivity in warm climates? J. Dairy Sci 94:2147-2158.

Berry, D., L. Shalloo, A. Cromie, V. Olori, R. Veerkamp, P. Dillon, P. Amer, R. Evans, F. Kearney, and B. Wickham. 2007. The economic breeding index: A generation on. Accessed Jan. 7, 2014 http://www.icbf.com/publications/files/The_Economic_breeding a_generation_on_Dec_2007.pdf.

Boettcher, P. J., J. Faheti, and M. M. Schutz. 2003. Genotype $\times$ environment interactions in conventional versus pasture-based dairies in Canada. J. Dairy Sci. 86:383-389.

Buckley, F., K. O'Sullivan, J. F. Mee, R. D. Evans, and P. Dillon. 2003. Relationships among milk yield, body condition, cow weight, and reproduction in spring-calved Holstein-Friesians. J. Dairy Sci. 86:2308-2319

Butler, S. T., L. Shalloo, and J. J. Murphy. 2010. Extended lactations in a seasonal-calving pastoral system of production to modulate the effects of reproductive failure. J. Dairy Sci. 93:1283-1295.

Charlton, G. L., S. M. Rutter, M. East, and L. A. Sinclair. 2011. Effects of providing total mixed rations indoors and on pasture on the behavior of lactating dairy cattle and their preference to be indoors or on pasture. J. Dairy Sci. 94:3875-3884.

Clark, D. A., C. V. C. Phyn, M. J. Tong, S. J. Collis, and D. E. Dalley. 2006. A systems comparison of once- versus twice-daily milking of pastured dairy cows. J. Dairy Sci. 89:1854-1862.

Cole, J. B., P. M. VanRaden, and Multi-State Project S-1040. 2010 Net merit as a measure of lifetime profit: 2010 revision. AIPL Res. Rep. NM\$4 (12-09). Accessed Nov. 1, 2011. http://aipl.arsusda. gov/reference/nmcalc-2010.htm.

Cummins, S. B., P. Lonergan, A. C. O. Evans, D. P. Berry, R. D Evans, and S. T. Butler. 2012a. Genetic merit for fertility traits in Holstein cows: I. Production characteristics and reproductive efficiency in a pasture-based system. J. Dairy Sci. 95:1310-1322.

Cummins, S. B., P. Lonergan, A. C. O. Evans, and S. T. Butler. 2012b. Genetic merit for fertility traits in Holstein cows: II. Ovarian follicular and corpus luteum dynamics, reproductive hormones, and estrus behavior. J. Dairy Sci. 95:3698-3710.

DairyNZ. 2010. Facts and Figures for New Zealand Dairy Farmers. Accessed Nov. 24, 2013. http://www.dairynz.co.nz/Publications/ FactsFigures/2010/.

DairyNZ. 2013a. New Zealand Dairy Statistics 2011-2012. Accessed Nov. 24, 2013. http://www.dairynz.co.nz/page/pageid/ 2145866855/New_Zealand_Dairy_Statistics.

DairyNZ. 2013b. New Zealand Animal Evaluation. Accessed Jan. 7, 2014. http://www.nzael.co.nz/.

Dillon, P., D. P. Berry, R. D. Evans, F. Buckley, and B. Horan. 2006 Consequences of genetic selection for increased milk production in European seasonal pasture based systems of milk production. Livest. Sci. 99:141-158.

Dini, Y., J. Gere, C. Briano, M. Manetti, P. Juliarena, V. Picasso, R. Gratton, and L. Astigarraga. 2012. Methane emission and milk production of dairy cows grazing pastures rich in legumes or rich in grasses in Uruguay. Animal 2:288-300.

Elzo, M. A., A. Jara, and N. Barria. 2004. Genetic parameters and trends in the Chilean multibreed dairy cattle population. J. Dairy Sci. $87: 1506-1518$

Fahey, A. G., M. M. Schutz, D. L. Lofgren, A. P. Schinckel, and T. S. Stewart. 2007. Genotype by environment interaction for produc- tion traits while accounting for heteroscedasticity. J. Dairy Sci 90:3889-3899

Ferreira, G. 2013. Reproductive performance of dairy farms in western Buenos Aires province, Argentina. J. Dairy Sci. 96:8075-8080.

Ferris, C., K. Molyneaux, A. McKeague, D. Patterson, S. Mayne, D. Kilpatrick, and F. Gordon. 2012. A comparison of the performance of Holstein-Friesian and Norwegian Red cows on Northern Ireland dairy farms. AgriSearch Farmer Booklet 22 (20 pp); Agriculture, Food and Biosciences Institute, Hillsborough, Northern Ireland. Accessed Dec. 12, 2013. http://www.agrisearch.org/publications/ farmerbooklets?task=document.viewdoc\&id $=12$

Fontaneli, R. S., L. E. Sollenberger, R. C. Littell, and C. R. Staples. 2005. Performance of lactating dairy cows managed on pasturebased or in freestall barn-feeding systems. J. Dairy Sci. 88:12641276.

Fredeen, A. H., T. Astatkie, R. W. Jannasch, and R. C. Martin. 2002. Productivity of grazing Holstein cows in Atlantic Canada. J. Dairy Sci. 85:1331-1338.

Geno. 2010. Norwegian Red Characteristics. Accessed Jan. 8, 2014. http: //www.genoglobal.no/Home/Norwegian-Red-Characteristics/.

Grainger, C., M. J. Auldist, G. O'Brien, K. L. Macmillan, and C. Culley. 2009. Effect of type of diet and energy intake on milk production of Holstein-Friesian cows with extended lactations. J. Dairy Sci. 92:1479-1492.

Hanson, G. D., L. C. Cunningham, M. J. Morehart, and R. L. Parsons, 1998. Profitability of moderate intensive grazing of dairy cows in the Northeast. J. Dairy Sci. 81:821-829.

Hare, E. H. D. N., and J. R. Wright. 2006. Trends in calving ages and calving intervals for dairy cattle breeds in the United States. J. Dairy Sci. 89:365-370.

Harris, B. L. 2005. Breeding dairy cows for the future in New Zealand. N. Z. Vet. J. 53:384-390.

Harris, B. L., and E. S. Kolver. 2001. Review of holsteinization on intensive pastoral dairy farming in New Zealand. J. Dairy Sci. 84(E-Suppl.):E56-E61.

Harris, B. L., A. W. Winkelman, and L. J. Burton. 2000. Comparisons of fertility measures in strains of Holstein-Friesian cows, Jersey cows and their crosses. Proc. Massey Dairy Farmers Conference. Massey University, Palmerston North, New Zealand.

Hazel, A. R., B. J. Heins, A. J. Seykora, and L. B. Hansen. 2014 Production, fertility, survival, and body measurements of Montbeliarde-sired crossbreds compared with pure Holsteins during their first 5 lactations. J. Dairy Sci. 97:2512-2525.

Hazel, L. N. 1943. The genetic basis for constructing selection indexes Genetics 28:476-490.

Heins, B. J., L. B. Hansen, and A. J. Seykora. 2006a. Production of pure Holsteins versus crossbreds of Holstein with Normande, Montbeliarde, and Scandinavian Red. J. Dairy Sci. 89:2799-2804.

Heins, B. J., L. B. Hansen, and A. J. Seykora. 2006b. Fertility and survival of pure Holsteins versus crossbreds of Holstein with Normande, Montbeliarde, and Scandinavian Red. J. Dairy Sci 89:4944-4951.

Herlihy, M. M., D. P. Berry, M. A. Crowe, M. G. Diskin, and S. T. Butler. 2011. Evaluation of protocols to synchronize estrus and ovulation in seasonal calving pasture-based dairy production systems. J. Dairy Sci. 94:4488-4501.

Herlihy, M. M., M. A. Crowe, D. P. Berry, M. G. Diskin, and S. T. Butler. 2013. Factors associated with fertility outcomes in cows treated with protocols to synchronize estrus and ovulation in seasonal-calving, pasture-based dairy production systems. J. Dairy Sci. 96:1485-1498.

Hickson, R. E., N. Lopez-Villalobos, D. E. Dalley, D. A. Clark, and C. W. Holmes. 2006. Yields and persistency of lactation in Friesian and Jersey cows milked once daily. J. Dairy Sci. 89:2017-2024.

Horan, B., P. Dillon, P. Faverdin, L. Delaby, F. Buckley, and M. Rath. 2005a. The interaction of strain of Holstein-Friesian cows and pasture-based feed systems on milk yield, body weight, and body condition score. J. Dairy Sci. 88:1231-1243.

Horan, B., J. F. Mee, P. O'Connor, M. Rath, and P. Dillon. 2005b. The effect of strain of Holstein-Friesian cow and feeding systems 
on postpartum ovarian function, animal production and conception rate to first service. Theriogenology 63:950-971.

Jamrozik, J., J. Fatehi, G. J. Kistemaker, and L. R. Schaeffer. 2005. Estimates of genetic parameters for Canadian Holstein female reproduction traits. J. Dairy Sci. 88:2199-2208.

Kearney, J. F., M. M. Schutz, and P. J. Boettcher. 2004b. Genotype $\times$ environment interaction for grazing vs. confinement. II. Health and reproduction traits. J. Dairy Sci. 87:510-516.

Kearney, J. F., M. M. Schutz, P. J. Boettcher, and K. A. Weigel. 2004a. Genotype $\times$ environment interaction for grazing versus confinement. I. Production traits. J. Dairy Sci. 87:501-509.

Kolver, E. S., and L. D. Muller. 1998. Performance and nutrient intake of high producing Holstein cows consuming pasture or a total mixed ration. J. Dairy Sci. 81:1403-1411.

Kolver, E. S., J. R. Roche, C. R. Burke, J. K. Kay, and P. W. Aspin. 2007. Extending lactation in pasture-based dairy cows: I. Genotype and diet effect on milk and reproduction. J. Dairy Sci. 90:5518-5530.

Kriegl, T., and R. McNair. 2005. Pastures of plenty: Financial performance of Wisconsin grazing dairy farms. Accessed Dec. 24, 2013. http://cdp.wisc.edu/pdf/grzgfin1.pdf.

Lopez-Villalobos, N., D. J. Garrick, C. W. Holmes, H. T. Blair, and R. J. Spelman. 2000a. Effects of selection and crossbreeding strategies on industry profit in the New Zealand dairy industry. J. Dairy Sci. 83:164-172.

Lopez-Villalobos, N., D. J. Garrick, C. W. Holmes, H. T. Blair, and R. J. Spelman. 2000b. Profitabilities of some mating systems for dairy herds in New Zealand. J. Dairy Sci. 83:144-153.

Lucy, M. C. 2001. Reproductive loss in high-producing dairy cattle: Where will it end? J. Dairy Sci. 84:1277-1293.

Macdonald, K. A., D. Beca, J. W. Penno, J. A. S. Lancaster, and J. R. Roche. 2011. Short communication: Effect of stocking rate on the economics of pasture-based dairy farms. J. Dairy Sci. 94:25812586.

Macdonald, K. A., L. R. McNaughton, G. A. Verkerk, J. W. Penno, L. J. Burton, D. P. Berry, P. J. S. Gore, J. A. S. Lancaster, and C. W. Holmes. 2007. A comparison of three strains of Holstein-Friesian cows grazed on pasture: Growth, development, and puberty. J. Dairy Sci. 90:3993-4003.

Macdonald, K. A., J. W. Penno, J. A. S. Lancaster, and J. R. Roche. 2008a. Effect of stocking rate on pasture production, milk production, and reproduction of dairy cows in pasture-based systems. J. Dairy Sci. 91:2151-2163.

Macdonald, K. A., G. A. Verkerk, B. S. Thorrold, J. E. Pryce, J. W. Penno, L. R. McNaughton, L. J. Burton, J. A. S. Lancaster, J. H. Williamson, and C. W. Holmes. 2008b. A comparison of three strains of Holstein-Friesian grazed on pasture and managed under different feed allowances. J. Dairy Sci. 91:1693-1707.

Macoon, B., L. E. Sollenberger, C. R. Staples, K. M. Portier, J. H. Fike, and J. E. Moorell. 2011. Grazing management and supplementation effects on forage and dairy cow performance on coolseason pastures in the southeastern United States. J. Dairy Sci. 94:3949-3959.

Madalena, F. E., K. Agyemang, R. C. Cardellino, and G. L. Jain. 2002. Genetic improvement in medium- to low-input systems of animal production. Experiences to date. 7th World Congress on Genetics Applied to Livestock Production. Montpellier, France. Accessed Dec. 3, 2013. http://www.fernandomadalena.com/site_ arquivos/301.pdf.

McCarthy, B., K. M. Pierce, L. Delaby, A. Brennan, and B. Horan. 2012. The effect of stocking rate and calving date on reproductive performance, body state, and metabolic and health parameters of Holstein-Friesian dairy cows. J. Dairy Sci. 95:1337-1348.

McCormick, M., V. Moreira, D. McKean, S. Forbes, and R. Walz. 2011. Oat pasture mob grazing demonstration with high-producing Holstein cows. Southeast Research Station Field Day Summaries. Louisiana State Univ, Ag. Ctr. Franklinton, LA.

McDougall, S., and C. Compton. 2005. Reproductive performance of anestrous dairy cows treated with progesterone and estradiol benzoate. J. Dairy Sci. 88:2388-2400.
Miglior, F., B. L. Muir, and B. J. Van Doormaal. 2005. Selection indices in Holstein cattle of various countries. J. Dairy Sci. 88:12551263.

Morton, J. 2011. Incalf fertility data project Dairy Australia 2011. Accessed Jan. 8, 2014. http://www.dairyaustralia.com.au/Home/ Standard-Items/ /media/Documents/Animal\%20management/ Fertility/fertility\%20data/InCalf\%20Fertility\%20Data\%20Project \%202011\%20FINAL\%2029Aug11\%20LARGE\%20V2.pdf.

Norman, H. D., J. R. Wright, M. T. Kuhn, S. M. Hubbard, J. B. Cole, and P. M. VanRaden. 2009. Genetic and environmental factors that affect gestation length in dairy cattle. J. Dairy Sci. 92:2259-2269.

Norman, H. D., J. R. Wright, and R. L. Powell. 2006. Is there a need for different genetics in dairy grazing systems? Proc. 6th MidAtlantic Dairy Grazing Conf., Goldsboro, NC, Oct. 31-Nov. 1, pp. 1-5. Accessed Dec. 26, 2013. http://aipl.arsusda.gov/publish/ other/2006/Mid-Atlantic.pdf.

O'Mara, F. 2008. Food and Agriculture Organization of the United Nations Country Pasture/Forage Resource Profile: Ireland. Accessed 27 Mar. 2014. http://www.fao.org/ag/agp/AGPC/doc/ Counprof/Ireland/Ireland.htm.

Olori, V. E., T. H. E. Meuwissen, and R. F. Veerkamp. 2002. Calving interval and survival breeding values as measure of cow fertility in a pasture-based production system with seasonal calving. J. Dairy Sci. 85:689-696.

Parker, W. J., L. D. Muller, and D. R. Buckmaster. 1992. Management and economic implications of intensive grazing on dairy farms in the Northeastern states. J. Dairy Sci. 75:2587-2597.

Pedernera, M., S. C. Garcia, A. Horagadoga, I. Barchia, and W. J. Fulkerson. 2008. Energy balance and reproduction on dairy cows fed to achieve low or high milk production on a pasture-based system. J. Dairy Sci. 91:3896-3907.

Penasa, M., N. López-Villalobos, R. D. Evans, A. R. Cromie, R. Dal Zotto, and M. Cassandro. 2010. Crossbreeding effects on milk yield traits and calving interval in spring-calving dairy cows. J. Anim. Breed. Genet. 127:300-307.

Prendiville, R., E. Lewis, K. M. Pierce, and F. Buckley. 2010. Comparative grazing behavior of lactating Holstein-Friesian, Jersey, and Jersey $\times$ Holstein-Friesian dairy cows and its association with intake capacity and production efficiency. J. Dairy Sci. 93:764-774.

Prendiville, R., K. M. Pierce, and F. Buckley. 2009. An evaluation of production efficiencies among lactating Holstein-Friesian, Jersey, and Jersey $\times$ Holstein-Friesian cows at pasture. J. Dairy Sci. 92:6176-6185.

Pryce, J. E., and B. L. Harris. 2006. Genetics of body condition score in New Zealand dairy cows. J. Dairy Sci. 89:4424-4432.

Pryce, J. E., M. D. Royal, P. C. Garnsworthy, and I. L. Mao. 2004. Fertility in the high-producing dairy cow. Livest. Prod. Sci. $86: 125-135$.

Pryce, J. E., and R. F. Veerkamp. 2001. The incorporation of fertility indices in genetic improvement programmes. BSAS Occasional Meeting - Fertility in the High Producing Dairy Cow, Galway, Ireland. Br. Soc. Anim. Sci. Publ. 26:237-249.

Roche, J. R., D. P. Berry, and E. S. Kolver. 2006. Holstein-Friesian strain and feed effects on milk production, body weight, and body condition score profiles in grazing dairy cows. J. Dairy Sci. 89:3532-3543

Schaeffer, L. R., E. B. Burnside, P. Glover, and J. Fatehi. 2011. Crossbreeding results in Canadian dairy cattle for production, reproduction and conformation. Open Agric. J. 5:63-72.

Shalloo, L., P. Dillon, M. Rath, and M. Wallace. 2004. Description and validation of the Moorepark dairy system model. J. Dairy Sci. 87:1945-1959.

Snijders, S. E. M., P. G. Dillon, K. J. O'Farrell, M. Diskin, A. R. G. Wylie, D. O'Callaghan, M. Rath, and M. P. Boland. 2001. Genetic merit for milk production and reproductive success in dairy cows. Anim. Reprod. Sci. 65:17-31.

Soder, K. J., and C. A. Rotz. 2001. Economic and environmental impact of four levels of concentrate supplementation in grazing dairy herds. J. Dairy Sci. 84:2560-2572. 
Sørensen, M. K., E. Norberg, J. Pedersen, and L. G. Christensen. 2008. Invited review: Crossbreeding in dairy cattle: A Danish perspective. J. Dairy Sci. 91:4116-4128.

Soriano, F. D., C. E. Polan, and C. N. Miller. 2001. Supplementing pasture to lactating Holsteins fed a total mixed ration diet. J. Dairy Sci. 84:2460-2468.

Tucker, C. B., D. E. Dalley, J.-L. K. Burke, and D. A. Clark. 2007. Milking cows once daily influences behavior and udder firmness at peak and mid lactation. J. Dairy Sci. 90:1692-1703.

USDA-NASS (National Agriculture Statistics Service). 2010. 2010 dairy producer survey. Accessed Apr. 21, 2014. http://www.nass.usda. gov/Statistics_by_State/Wisconsin/Publications/Dairy/Dairy_ OP_Release_10.pdf.

Vance, E. R., C. P. Ferris, C. T. Elliott, H. M. Hartley, and D. J. Kilpatrick. 2013. Comparison of the performance of Holstein-Friesian and Jersey $\times$ Holstein-Friesian crossbred dairy cows within three contrasting grassland-based systems of milk production. Livest. Sci. 151:66-79

VanRaden, P. M. 2004. Invited review: Selection on net merit to improve lifetime profit. J. Dairy Sci. 87:3125-3131.

VanRaden, P. M., K. M. Olson, D. J. Null, and J. L. Hutchison. 2011. Harmful recessive effects on fertility detected by absence of homozygous haplotypes. J. Dairy Sci. 94:6153-6161.

Vibart, R. E. 2006. Performance of lactating dairy cows fed varying levels of total mixed ration and pasture. PhD Thesis. North Carolina State Univ., Raleigh. Accessed Dec. 23, 2013. http:// repository.lib.ncsu.edu/ir/bitstream/1840.16/3665/1/etd.pdf.

Vibart, R. E., S. P. Washburn, J. T. Green Jr., G. A. Benson, C. M. Williams, D. Pacheco, and N. Lopez-Villalobos. 2012. Effects of feeding strategy on milk production, reproduction, pasture utilization, and economics of autumn-calving dairy cows in eastern North Carolina. J. Dairy Sci. 95:997-1010.

Visscher, P. M., P. J. Bowman, and M. E. Goddard. 1994. Breeding objectives for pasture based dairy production systems. Livest. Prod. Sci. 40:123-137.

Walsh, S., F. Buckley, D. P. Berry, M. Rath, K. Pierce, N. Byrne, and P. Dillon. 2007. Effects of breed, feeding system, and parity on udder health and milking characteristics. J. Dairy Sci. 90:5767-5779.

Walsh, S., F. Buckley, K. Pierce, N. Byme, J. Patton, and P. Dillon. 2008. Effects of breed and feeding system on milk production, body weight, body condition score, reproductive performance, and postpartum ovarian function. J. Dairy Sci. 91:4401-4413.

Washburn, S. P., W. J. Silvia, C. H. Brown, B. T. McDaniel, and A. J. McAllister. 2002a. Trends in reproductive performance in Southeastern Holstein and Jersey DHI herds. J. Dairy Sci. 85:244-251.

Washburn, S. P., S. L. White, J. T. Green Jr., and G. A. Benson 2002b. Reproduction, mastitis, and body condition of seasonally calved Holstein and Jersey cows in confinement or pasture systems. J. Dairy Sci. 85:105-111.

Weigel, K. A., P. C. Hoffman, W. Herring, and T. J. Lawlor Jr. 2012 Potential gains in lifetime net merit from genomic testing of cows, heifers, and calves on commercial dairy farms. J. Dairy Sci. 95:2215-2225

Weigel, K. A., T. Kriegl, and A. L. Pohlman. 1999. Genetic analysis of dairy cattle production traits in a management intensive rotational grazing environment. J. Dairy Sci. 82:191-195.

White, S. L., G. A. Benson, S. P. Washburn, and J. T. Green Jr. 2002. Milk production and economic measures in confinement or pasture systems using seasonally calved Holstein and Jersey cows. J. Dairy Sci. 85:95-104.

Wiggans, G. R., P. M. VanRaden, and T. A. Cooper. 2011. The genomic evaluation system in the United States: Past, present, future. J. Dairy Sci. 94:3202-3211.

Wildman, E. E., G. M. Jones, P. E. Wagner, R. L. Boman, H. F. Troutt, and T. N. Lesch. 1982. A dairy cow body condition scoring system and its relationship to selected production characteristics. J. Dairy Sci. 65:495-501

Williams, C. M. 2007. Effects of crossbreeding on puberty, postpartum cyclicity, and fertility in pasture-based dairy cattle. MS Thesis. North Carolina State Univ., Raleigh. Accessed Dec. 12, 2013. http://repository.lib.ncsu.edu/ir/bitstream/1840.16/2042/1/etd. pdf.

Winsten, J. R., C. D. Kerchner, A. Richardson, A. Lichau, and J. M. Hyman. 2010. Trends in the Northeast dairy industry: Large-scale modern confinement feeding and management-intensive grazing. J. Dairy Sci. 93:1759-1769.

Wu, Z., V. R. Kanneganti, L. J. Massingill, M. C. Wiltbank, R. P. Walgenbach, and L. D. Satter. 2001. Milk production of fall-calving dairy cows during summer grazing of grass or grass-clover pasture. J. Dairy Sci. 84:1166-1173. 